\title{
FARM DIVERSIFICATION IN THE CENTRAL HIGHLANDS OF ETHIOPIA: PATTERNS, DETERMINANTS AND ITS EFFECT ON HOUSEHOLD INCOME
}

\author{
Wuletaw MEKURIA $^{1}$ (D), Kindu MEKONNEN ${ }^{2}$, Marelign ADUGNA ${ }^{1 *}$ (D)
}

\author{
Address: \\ ${ }^{1}$ College of Agriculture and Environmental Sciences, University of Gondar, P.O. Box 196, Gondar, Ethiopia. \\ ${ }^{2}$ Crop-livestock Scientist, International Livestock Research Institute (ILRI), P.O. Box 5689, Addis Ababa, Ethiopia. \\ * Corresponding author's e-mail: marlynk3@gmail.com
}

\begin{abstract}
Crop-livestock production is the major farming system in the highlands of Ethiopia. This study aimed to describe croplivestock diversification pattern, examine determinants of diversification patterns, and evaluate effects of divers ification on household income. Principal component analysis (PCA), seemingly unrelated regression (SUR) and ordinary least square (OLS) regression models were employed. Five major crop-livestock diversification patterns: sheep and goat, staple crops, chicken, vegetables, and animal feed-based farming were identified. The SUR model revealed that sex, education, income, extension contact, land size, market and road distance, irrigated land, and household size were significant factors that influence crop-livestock diversification patterns. It is also found that sheep and goat, vegetable, and chicken-based farming were significant production patterns that had positive effects on household income. We suggest that adoptive and adaptive agricultural practices such as small-scale irrigation, chicken rearing and sheep-based production patterns are the most potential farming systems in the highlands of Ethiopia.
\end{abstract}

Keywords: Agriculture, competition; diversification pattern; mixed farming JEL: C12, C38, D13, Q12

\section{INTRODUCTION}

Agriculture is the most common livelihood strategy and basis for Ethiopian economy (Dinku, 2018). The agriculture sector contributes for $39 \%$ of national GDP (UNDP, 2018), and $83 \%$ of the population is engaged in agriculture (ILO, 2014). The majority (90\%) of the rural population rely mainly on crop-livestock systems and natural resources for their livelihoods, and nearly $60 \%$ of the land coverage is under non-pastoral production systems (Lebeda et al., 2010; Dinku, 2018). Mixed croplivestock production is a regular activity in the highlands of the country (Asante et al., 2017). Heterogeneous farming systems have economic, social, and ecological advantages and the sources of food, household income, foreign exchange earnings, and response for employment opportunities and raw materials for industries (Nigussie and Alemayehu, 2013; Martin et al., 2016). Moreover, most households use crops and livestock for risk reduction and coping strategies (Berhe, 2011; Kassie, Kim and Fellizar, 2017). In uncertain environment and unstable marketing situations, diversified farms are less risky than monocul tures (Shahbaz et al., 2017).

Many literatures argue for a range of farm activities as a means to minimize income insecurity and insurance against crop failures (Alemayehu, Dorosh and Sinafikeh, 2011; Lin, 2011; Liniger et al., 2011; Herrero et al., 2012). Mixed crop-livestock systems provide bio-diversity and ecosystem services (Nkonya $\boldsymbol{e t}$ al., 2011; IFAD, 2013). The systems reduce vulnerability to food insecurity. On top of this, mixed farming provides recreational, cultural and spiritual significance (IFAD,
2010; Liniger et al, 2011; Moraine et al., 2014). Agricultural intensification is also considered as another alternative strategy for smallholders (Shideed and El Mourid, 2005; Manyong, Okikeb and Williams, 2006; liyama et al., 2007a). Population pressure is the key driver for agricultural intensification and production dynamics in the farming systems (Boserup, 1965, 1981; McIntire, Bourzat and Pingali, 1992). However, intensification has been criticized for environmental pollution, soil deterioration, land degradation, and nutrient depletion (IFAD 2013). Many researchers have tried to mediate the contrasted debates between diversification and intensification in agriculture (for instance, Daniel, 2010; Todaro and Smith, 2012). The latter is more appropriated for large-scale, location specific and capitalintensive enterprises.

Even though the government of Ethiopia has made efforts to improve the livelihoods of the rural poor, persistent challenges have been continued on agriculture for centuries. Food insecurity and high population density have always been adversely affecting the landscape situations of the highlands (Lin, 2011; Kuria et al., 2014). Population pressure, land fragmentation, soil erosion, and poverty are the main confronts in the highlands agroclimates (IFAD, 2013; Abate, 2014; Haregeweyn et al., 2015). At country level, one-third of the rural households could not produce adequate food for the rising population and exhibited large rates of malnutrition (Harerro et al., 2012). The population living below poverty line and under nourishment is 29.6 and $35.0 \%$, respectively (FAO, 2014). The ever-increasing human population and severe land fragmentation made the food situations worsened 
(Sisay, Degsew and Mekuria, 2018). Despite apparent yield improvements have been reported, evidences on agricultural technologies particularly crop varieties and animal breeds are not overwhelming (Mekuria and Mekonnen, 2017).

Mekuria et al. (2018) have also found that competition among crop-livestock activities for land resources is increasing. Therefore, it is crucial to identify patterns for crop-livestock production and determine associated factors to alleviate such competitions. One of the strategies, often adopted to tackle livelihood confronts, is producing integrated diversified crop-livestock activities. Crop-livestock diversity in turn helps to improve dietary diversity (Sibhatu, Krishina and Qaim, 2015). Diversified agriculture has a potential to produce adequate food, provide sufficient incomes, and maintain agro-ecosystem services (Rudel et al., 2016). Despite mixed farming contributes in managing production risks, previous studies on agricultural diversification are minimal as mainly focused on livelihoods and crop diversification (Mesfin, Fufa and Haji, 2011; Rehima et al., 2013; Sibhatu, Krishina and Qaim, 2015). Moreover, there is no study conducted in Ethiopia that addressed crop-livestock diversification patterns and determinants of diversification. Therefore, the objectives of the paper were (i) to examine crop-livestock diversification patterns, (ii) analyze determinants of diversification patterns and, (iii) evaluate effects of diversification on household income in the farming systems.

\section{DATA AND METHODS}

\section{Description of the study area}

The study watershed was located in Gudo Beret Kebele, Basona Worana district, North Shewa Zone, Amhara region, Ethiopia. The geographical coordinates are situated between $9^{\circ} 76^{\prime}$ to $9^{\circ} 81^{\prime}$ of northern latitudes and $39^{\circ} 65^{\prime}$ to $39^{\circ} 73^{\prime}$ eastern longitudes. The study watershed covered about 2425 ha of land. The altitude in the watershed ranges between 2828 and 3700 meter above sea level. The mean daytime temperature was between $2.4{ }^{\circ} \mathrm{C}$ and $19.2{ }^{\circ} \mathrm{C}$. The climate of the watershed was wet and moist highland with a bimodal rainfall pattern. The mean annual rainfall in the watershed was $1651 \mathrm{~mm}$. According to Kebele census (2016), the total population size of the study watershed was 2070 and 447 households.

The research watershed was characterized by mixed farming systems. The dominant livelihood sources include mainly subsistence crop cultivation, livestock husbandry, and plantation of eucalyptus woodlots. There was no natural forest in the watershed but eucalyptus trees around homesteads, hillsides, and gully buffers covered about $15.2 \%$ of the total study area (Tadesse and Tafere, 2017). Barley, wheat, faba bean, field pea, and vegetables are the major crops grown in the watershed, while the major livestock types include cattle, sheep, and equines. In often times, livestock husbandry has been practiced in combination with crop production and eucalyptus plantation. The sources of animal feed include crop residue, industrial byproducts, and open grazing in communal and individual plots. Despite livestock were allowed to graze under the eucalyptus woodlots, the high density of woodlots inhibited pasture growth for animals.

\section{Sampling techniques and data collection}

A three-stage sampling procedure was employed. At first stage, the study district was selected purposively. Similarly, the study watershed was selected purposively for the reason that intensive mixed farming systems have been practiced. The watershed was also a part of the USAID; feed the future funded Africa RISING project in the highlands of the country. In this watershed, 211 household-heads were randomly selected. The study was based on cross-sectional data collected in the watershed between May and June of 2016. Questions in the interview schedule were prepared to capture the details of farm households. Training on methods of data collection was conducted for enumerators. Finally, the data were collected at household level that include demographic, socioeconomic, institutional, and biophysical variables such as crop varieties, livestock breeds, incomes, and others.

\section{Methods of data analysis}

Descriptive statistics such as percentage, frequency, standard deviation, mean, and specifically a multivariate analytical technique PCA was employed to determine crop-livestock diversification patterns. Econometric methods such as SUR and Linear regression models were also used to examine determinants of diversification and effects of diversification on household income.

\section{Model specification}

PCA analysis: A multivariate statistical technique, PCA was employed to identify the dominant crop-livestock diversification patterns (Lesschen and Verburg, 2005; liyama, Maitima and Kariuki, 2007b; Kebede et al., 2016). PCA is used to derive new sets of reduced and uncorrelated variables-diversification patterns (Abdi and Williams, 2010; Keho, 2012). PCA was derived from correlation matrix once different units of crop-livestock activities were standardized using z-score (Gujarati 2003:173; Manyong, Okikeb and Williams, 2006). Two criteria were employed to retain major components. High percentage of the total variation in the original variables is the first criterion (Iiyama, Maitima and Kariuki, 2007b) and as a rule of thumb Eigen values greater than 1.0 is the second criterion (Manyong, Okikeb and Williams, 2006; Abdi and Williams, 2010). The formula was adapted in Keho (2012).

$Y_{n}=\alpha_{n 1}\left(X_{1}\right)+\alpha_{n 2}\left(X_{2}\right)+\cdots+\alpha_{n p}\left(X_{p}\right)$

\section{Where:}

$Y_{n}$, the subject score on principal component indicates patterns and to what extent households engage in the production system; $\alpha_{n 1}$ is the weight for variable $X_{1}$ in creating the component $Y_{n} ; X_{1}, X_{2}, \ldots X_{p}$ are variables or activities; $\alpha_{n p}$ is regression coefficient for observed variable $P$; and $X_{p}$ is subject score on observed variable $p$. 


\section{Model for determinants of diversification}

Determinants for the major components of mixed farming systems were modelled using SUR assuming that error terms between components are expected to be correlated. SUR model is an efficient estimator of coefficients compared with OLS regression when the error terms between equations are correlated. The former provides a more robust parameter of estimates of coefficients, standard errors, and covariance compared to OLS regression (Liew, 2017). SUR model estimates more than two equations simultaneously. The parameters of each equation take information provided by the other equation into account (Cadavez and Henningsen, 2012).

$Y_{i}=X_{i} \beta_{i}+\varepsilon_{i} \quad i=1,2, \ldots, M$

Where:

$Y_{i}$ is $\left(T^{*} l\right)$ vector with elements $y_{t i}, X_{i}$ is $\left(T^{*} K_{i}\right)$ matrix whose columns represent $T$ observation or an explanatory variable in the $i^{\text {th }}$ equation, $\beta_{i}$ is $\left(K_{i}^{*} l\right)$ vector with elements $\beta_{i j}, M$ is parameters of equations and $\varepsilon_{i}=$ $\left[\varepsilon_{1}^{\prime} \varepsilon_{2}^{\prime}, \varepsilon_{3}^{\prime}, \ldots \varepsilon_{M}^{\prime}\right]$ is vector of disturbances.

The independent variables were selected based on previous empirical studies and the data gathered from household survey. The hypothesized variables were expected to influence diversification patterns differently; either positively or negatively (Table 1).

\section{Model for the effect of diversification on household income}

The impacts of crop-livestock diversification patterns on household income were modelled using OLS regression. The formula was adapted in Greene (2002) and computed as Eq. 3.

$Y_{i}=X \beta+\varepsilon_{i}$

Where:

$Y$ is $t$ he proportion of annual income obtained in the $i^{t h}$ farmer, $X$ is a vector of diversification patterns determining the amount of household income $\beta$ is a vector of parameters to be estimated and $\varepsilon_{i}$ is the error term.

\section{RESULTS}

\section{Socio-economic attributes of households}

In the study area, $29 \%$ of households were women-headed. The average household members were 4.5. Man equivalent and active labour force were accounted for 3.9 and 2.9 per household, respectively. The mean age of household heads was 44 years with a minimum and maximum of 23 and 82 years old. The age for the majority (90.5\%) of household heads were between 23 and 65 years indicating that almost all household heads are in the range of active age. In terms of educational status, about $21 \%$ of household heads were illiterate while $43 \%$ household heads could read and write. The result also showed that, the mean land holding size was 1.3 hectare with a minimum of 0.1 and a maximum 4 hectares. Households have used inorganic and organic fertilizers for crop production. The majority of households $(85 \%)$ used on average $100 \mathrm{~kg}$ compost while $58 \%$ of households applied on average $62 \mathrm{~kg}$ of inorganic fertilizer per household. Some households $(30 \%)$ used on average $52 \mathrm{~kg}$ of improved seed (Table 2), mainly barley and wheat varieties.

Extension service is an advice that informs and influences rural households' decision while extension contact is the frequency of interaction of development agents with farmers for advisory services (Anderson and Feder, 2003) and technical supports. Extension service has immense roles for technology transfer. Nearly $23 \%$ of households had no contact with development agents throughout a year, while $39 \%$ and $28 \%$ of households had one and two contacts in monthly basis. Limited number of households $(10 \%)$ could access three to five contacts per month. The local market, asphalt road, health clinic, elementary schools, electric power, potable water, and churches are key institutions and infrastructures found in the watershed.

Table 1: Independent variables in relation to crop-livestock diversification patterns

\begin{tabular}{|c|c|c|}
\hline Acronyms & Variable explanations and measurements & Hypothesis \\
\hline \multicolumn{3}{|c|}{ Dependent variables $\left(Y_{i}\right)$} \\
\hline CLDP & Crop-Livestock Diversification Patterns & \\
\hline \multicolumn{3}{|c|}{ Independent variables $\left(X_{i}\right)$} \\
\hline SEX & Sex of household head ( $1=$ male; $0=$ otherwise $)$ & $+($ male $)$ \\
\hline $\mathrm{AGE}$ & Age of household head measured in years & + \\
\hline EDUC & Educational level of household head in class years & - \\
\hline LABOR & Household labor measured in man-equivalent & + \\
\hline HHSIZE & Household size measured in number & - \\
\hline LAND & Land holding size in ha & + \\
\hline INCOME & Annual household income in \$USD* & + \\
\hline IRRIGAT & Irrigated land size in ha & + \\
\hline CREDIT & Access to credit ( $1=$ access to credit; $0=$ otherwise $)$ & + \\
\hline EXTEN & Extension contact in number of days per year & + \\
\hline DMKT & $\begin{array}{l}\text { Distance between household's residence and the nearest local market measured in } \\
\text { walking minutes }\end{array}$ & - \\
\hline DROAD & $\begin{array}{l}\text { Distance between household's residence and the nearest asphalt road measured in } \\
\text { walking minutes }\end{array}$ & - \\
\hline
\end{tabular}

Note: *Official exchange rate1.00 US dollar =21.5 Ethiopian Birr (June, 2016) 
The nearest local market is Gudo Beret located at the center of the watershed. The main asphalt road crosses the small town of Gudo-Beret from southwest to northeast direction. Accesses to tarmac road and the expansion of market opportunities have increased demands for marketoriented commodities such as eucalyptus poles, crop yields, and livestock products.

Table 2: Socio-economic attributes of sample households Variable description Mean Std. Dev. Min Max

\begin{tabular}{lrrrr}
\hline Age of household head & 44.0 & 12.4 & 23.0 & 82.0 \\
Land holding size & 1.3 & 0.6 & 0.1 & 4.0 \\
Household labour & 2.9 & 1.3 & 1.0 & 7.0 \\
Household size & 4.5 & 1.8 & 1.0 & 10.0 \\
Annual income & 4.8 & 5.2 & 0.0 & 38.5 \\
Extension contacts & 1.3 & 1.1 & 0.0 & 5.0 \\
Market distance & 27.5 & 25.8 & 0.0 & 90.0 \\
Road distance & 18.4 & 20.1 & 1.0 & 90.0 \\
Irrigated land size & 0.1 & 0.1 & 0.0 & 0.3 \\
\hline Source: Survey data (2016) & & & &
\end{tabular}

Source: Survey data (2016)

\section{Crop-livestock diversification patterns}

Cereal crops were the most abundant varieties followed by pulses, and less land size was allocated for oil crops, oats, vegetables and potatoes. Almost every (99\%) household has grown crops and $94 \%$ of households rear livestock. Of the total cultivated area, wheat and barley were accounted for $48 \%$. Households also produced faba bean, field pea, lentil, vegetables, Irish potato, oats and linseed on small plots of land. Figure 1 shows the types and proportions of crop varieties and livestock breeds. According to Magurran (2004), diversities in crop species and animal breeds demonstrate the abundance while the extent to which one or more species or breeds dominate the watershed evenness. The percentage was calculated in terms of hectare for cultivated crops and TLU for number of livestock.

Cattle, equines, sheep, goat, and chicken were the major livestock types reared in the study watershed. Three-quarters $(75 \%)$ of the cattle population were indigenous breeds while $25 \%$ were improved breeds. The highest cattle population was oxen while sheep and chicken were the highest livestock population in number. Sheep production was the most common practice mainly for the source of household incomes through selling. The majority $(61 \%)$ of livestock population was livestock followed by sheep and goat (20\%), equine (18\%) and chicken $(1 \%)$ in terms of TLU. In total, thirteen variables were included in PCA, in which five principal components with Eigen values greater than one were retained. Consequently, five major types of farming patterns were identified. The five principal components explained almost $71 \%$ of the total variability. These crop-livestock diversification patterns are presented in Table 3 .

The first principal component explained $24.22 \%$ of the total variance and it is correlated substantially with sheep and goat, equines, and indigenous cattle production. This component represented a diversification pattern for animal production. Similarly, principal components II, III, IV, and V explained $20.13,9.47,8.56$, and $8.50 \%$ of the total variance, respectively.

\section{Determinants of crop-livestock diversification patterns}

After determining diversification patterns, the next task of this study was identifying factors that cause crop-livestock diversification. To carry out it, the diversification patterns were regressed against socio-economic, demographic, and institutional variables that are expected to affect diversification pattern using seemingly unrelated regression procedure. This method was selected because the error terms between equations were assumed to be correlated. The estimated SUR model was tested for independence between the residual terms of diversification patterns using Breusch-Pagan test. The chi ${ }^{2}$ value of the test is 28.83 and rejected at $1 \%$ significant level. The test result confirmed that the SUR model is appropriate to estimate the simultaneous equations of the diversification patterns.

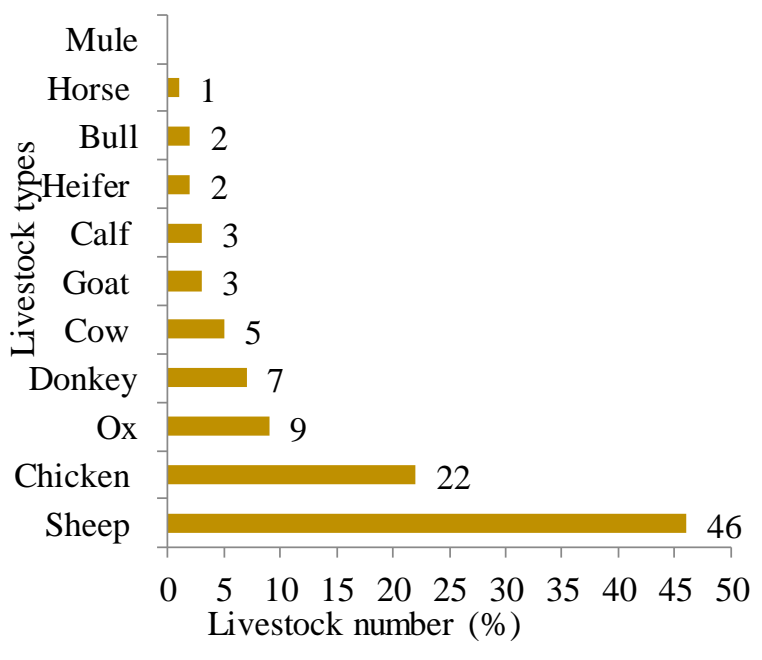

Figure 1: Crop and livestock diversity 
Table 3: The major crop-livestock diversification patterns (PCA result)

\begin{tabular}{|c|c|c|c|c|c|}
\hline \multirow[t]{3}{*}{ Major crop-livestock activities } & \multicolumn{5}{|c|}{ Major components } \\
\hline & CLD I & CLD II & CLD III & CLD IV & CLD V \\
\hline & Sheep and goats & Staple crops & Chicken & Vegetables & Animal feed \\
\hline Improved cattle (\%) & 0.56 & -0.29 & 0.31 & 0.09 & -0.17 \\
\hline Indigenous cattle (\%) & 0.72 & 0.39 & -0.14 & -0.02 & 0.17 \\
\hline Equines $(\%)$ & 0.76 & 0.23 & 0.03 & -0.08 & 0.05 \\
\hline Sheep and goat (\%) & 0.78 & 0.10 & 0.15 & 0.07 & 0.09 \\
\hline Chicken (\%) & 0.14 & 0.15 & 0.79 & -0.18 & -0.15 \\
\hline All animals (TLU) & 0.97 & 0.18 & 0.10 & 0.02 & 0.06 \\
\hline Cereal $(\%)$ & 0.28 & 0.66 & 0.01 & 0.23 & -0.03 \\
\hline Pulse (\%) & 0.12 & 0.79 & -0.03 & -0.04 & 0.06 \\
\hline Oil crops $(\%)$ & -0.03 & 0.58 & 0.21 & -0.35 & 0.00 \\
\hline Vegetables (\%) & -0.01 & 0.13 & -0.02 & 0.86 & -0.05 \\
\hline Oats $(\%)$ & 0.12 & 0.08 & -0.05 & -0.09 & 0.88 \\
\hline Total crop land (ha) & 0.22 & 0.92 & 0.00 & 0.24 & 0.07 \\
\hline Bee colonies (No) & 0.10 & -0.09 & 0.64 & 0.28 & 0.48 \\
\hline Eigen values & 3.15 & 2.62 & 1.23 & 1.11 & 1.11 \\
\hline$\%$ variance & 24.22 & 20.13 & 9.47 & 8.56 & 8.50 \\
\hline Com. explained variance & 24.22 & 44.35 & 53.82 & 62.38 & 70.88 \\
\hline
\end{tabular}

Note: Coefficients are factors loadings; extraction methods are principal component analysis. A rotation method is varimax with Kaiser Normalization.

Table 4: Results of SUR model $(\mathrm{N}=211)$

\begin{tabular}{|c|c|c|c|c|c|}
\hline \multirow{2}{*}{$\begin{array}{l}\text { Independent } \\
\text { Variables }\end{array}$} & \multicolumn{5}{|c|}{ Dependent Variables } \\
\hline & Sheep and goat & Staple crops & Chicken & Vegetables & Animal feed \\
\hline$\overline{\mathrm{AGE}}$ & $0.005(0.005)$ & $-0.007(0.005)$ & $0.005(0.006)$ & $-0.009(0.006)$ & $-0.008(0.006)$ \\
\hline EDUC & $0.015(0.048)$ & $-0.217^{* * *}(0.050)$ & $0.098(0.063)$ & $0.087(0.062)$ & $0.017(0.062)$ \\
\hline SEX & $0.350^{* * * *}(0.122)$ & $-0.054(0.128)$ & $-0.421^{* * * *}(0.160)$ & $0.151(0.157)$ & $0.133(0.158)$ \\
\hline LAND & $0.173^{*}(0.104)$ & $1.079^{* * *}(0.110)$ & $-0.168^{*}(0.136)$ & $0.454^{* * *}(0.134)$ & $-0.056(0.135)$ \\
\hline FLAB & $-0.022(0.060)$ & $0.013(0.064)$ & $-0.128(0.079)$ & $0.054(0.078)$ & $0.030(0.078)$ \\
\hline INCOME & $0.047^{*}(0.025)$ & $-0.012(0.026)$ & $0.051(0.032)$ & $0.038(0.032)$ & $-0.011(0.032)$ \\
\hline CREDIT & $-0.057(0.108)$ & $-0.136(0.114)$ & $-0.103(0.142)$ & $0.263(0.140)^{*}$ & $-0.045(0.140)$ \\
\hline EXTEN & $0.070(0.052)$ & $0.077(0.055)$ & $0.135^{* *}(0.068)$ & $0.026 \quad(0.067)$ & $-0.002 *(0.067)$ \\
\hline DMKT & $0.007^{*}(0.004)$ & $0.001(0.004)$ & $0.005(0.005)$ & $-0.011^{* *}(0.005)$ & $0.004(0.005)$ \\
\hline DROAD & $0.011^{* * *}(0.005)$ & $-0.006(0.005)$ & $-0.002(0.006)$ & $0.010 *(0.006)$ & $0.008(0.006)$ \\
\hline IRRIGAT & $-0.073(0.758)$ & $2.155^{* * * *}(0.797)$ & $0.643(0.993)$ & $-0.470(0.977)$ & $-1.308(0.981)$ \\
\hline HHSIZE & $0.156^{* * * *}(0.048)$ & $-0.080(0.051)$ & $0.093(0.063)$ & $-0.071(0.062)$ & $0.012(0.063)$ \\
\hline Cons & $-2.185^{* * * *}(0.340)$ & $-0.172(0.358)$ & $-0.611(0.445)$ & $-0.277(0.405)$ & $0.027(0.440)$ \\
\hline $\mathrm{R}^{2}$ & 0.464 & 0.406 & 0.080 & 0.109 & 0.100 \\
\hline $\mathrm{Chi}^{2}$ & $182.42 * * *$ & $144.38 * * *$ & $18.43 * *$ & $25.91 * * *$ & $23.67 * * *$ \\
\hline
\end{tabular}

Note: The parenthesis are standard errors; $*, * *$, and $* * *$ are significance at 10,5 , and $1 \%$.

The results of SUR model showed that different factors could influence crop-livestock diversification patterns. The hypothesized and tested independent variables were included in the model as shown in Table 4. The major determinants that influenced crop livestock diversification patterns were educational level of household heads, sex of household head, total land size, frequency of extension contact, distance to the nearest market place, distance to the nearest asphalt road, household size and land used for irrigation. The mixed farming systems had five diversification patterns in the study area. However, there was no a common factor that influenced all diversification patterns at the same time; due to the fact that diversification patterns have different attributes that were not influenced by common factors. Indeed, land size could affect the four diversification patterns at different significant levels with positive and negative coefficients. It implies crop and livestock-based diversification patterns had different socio-economic and bio-physical attributes.

EDUC: Educational level negatively affected the staple crop-based diversification patterns at $1 \%$ significant level. As a household head level of education increases by one year of schooling, the household decreases staplebased crop diversification by $21.7 \%$. Similarly, some other studies also found that education has negative effects on livestock husbandry, vegetable production, and croplivestock diversification (Mesfin, Fufa and Haji, 2011; Matsane and Oyekale 2014; Ojo et al., 2014; Kassie, Kim and Fellizar, 2017). There are possible explanations for negative relationships between education and farm diversification. As a farm household acquires skills and knowledge, either she /he may prefer specialized farm activities or search for non-farm employment opportunities. On the contrary, some previous studies revealed that a farmer with better level of education is more likely to adopt crop and livestock diversification 
compared to an illiterate farmer (Manyong, Okikeb and Williamsc, 2006; liyama, Maitima and Kariuki, 2007b). Thus, education can have mixed effects on farm activities depending on other factors.

SEX: Gender difference has mixed effects on farm diversification. Male-headed households affected sheep/goat-based production positively at $1 \%$ significant level. As a household head being male, the production pattern for sheep and goat increases by $35 \%$. On the contrary, a household head being male had negative correlation with chicken-based diversification and it was significant at $1 \%$. As a household leads by male, chickenbased production declines by $42.1 \%$. In the traditional farming systems, shepherd is for males while reproductive roles including poultry and child care is for females. Findings of other studies also revealed that male-headed households found to have positive correlation with cereal, vegetable and oat production while it is negative with livestock and chicken production (Ochieng, Owuor and Bebe, 2012; Xaba and Masuku, 2013; Asante et al., 2017).

LAND: Land is the most important variable on which different farm activities were carried out. Land size had positive effects on sheep/goat, staple and vegetable based production at $10 \%, 1 \%$ and $1 \%$ significant levels, respectively. As land size increases by 1.0 ha, the sheep/goat, staple, and vegetable-based production patterns increases by $17.3,107.9$, and $45.4 \%$, respectively. A farmer with more lands, can access pasture for livestock, eucalyptus trees, and vegetable crops. Rehima et al. (2013) and Asante et al. (2017) have found that land size has negative effects on farm diversification while Ojo et al. (2014) and Matsane and Oyekale (2014) found that land size is positive on oats, vegetables, and sheep and goat-based diversifications.

EXTEN: Agricultural extension service has positive effects on chicken-based diversification at 5\% significant level. As extension contact frequency increases by one day per month, chicken-based diversification pattern increases by $13.5 \%$. Extension contact is one of the major sources of information for agricultural practices and improved technologies such as animal breed, and other agricultural inputs. Extension is found to have positive correlation with crop diversification and chicken production in many studies (Ochieng, Owuor and Bebe, 2012; Rehima et al., 2013; Ojo et al., 2014). There are cases where extension contacts could adversely affect the crop-livestock systems (Manyong, Okikeb and Williams, 2006; Mesfin, Fufa and Haji, 2011).

DMKT: The relationship between market distance and vegetable-based diversification market was negative at 5\% significant level. As walking distance increases by one minute, vegetable-based diversification declines by $1.0 \%$. The possible reason may be households who reside near to the local market diversify their farm activities mainly vegetables for home consumption and market demands. Asante et al. (2017) reported that market distance has mixed effects on crop-livestock diversification. They found that market distance is negative towards the probability of adoption on crop production and the extent of decision on livestock production. Many studies reported that distance to the local market have negative correlations with crop diversification, vegetable production and chicken rearing (Mesfin, Fufa and Haji, 2011; Ochieng, Owuor and Bebe, 2012). In the study of Rehima et al. (2013), market distance is positive with crop diversification. Similarly, in this study market distance has positive correlation with sheep and goat-based production at $10 \%$ significant level. As market distance increases by one minute, sheep and goat-based production increases slightly by $0.7 \%$.

IRRIGAT: Irrigation land impacted the staple cropbased diversification pattern positively at $1 \%$ significant level. As irrigation land increases by 1 ha, the staple cropbased diversification pattern increases by $215.5 \%$. Hoffman and Livezey (1987) also reported similar findings. In the study of Rehima et al. (2013), irrigation is positively correlated with oats production and negatively associated with crop diversification.

DROAD: Road distance has positive correlation with both sheep and goat and vegetable based-diversification at $5 \%$ and $10 \%$ significant level, respectively. As road distance increases by one minute, the sheep and goat and vegetable-based diversification increases by $1 \%$. Sheep and goat-based farming is positive for market and road distance. It implies households who reside far from the center of the Kebele and the main asphalt road have better access to grazing fields for small ruminants.

HHSIZE: Household size has positive and significant correlation with sheep and goat-based diversification at $1 \%$ significant level. As household size increases by one member, the diversification for sheep and goat increases by $15.6 \%$. It implies that this pattern is labor intensive activity in the farming systems.

\section{Effects of crop-livestock diversification on household income}

In the study area, the three major sources of income include $68 \%$ farm, $25.3 \%$ non-farm, and $6.7 \%$ off-farm activities. This section is devoted to evaluate the effect of identified patterns on annual household income in the study area. Demographic, economic, social, institutional and bio-physical variables are potential factors that can affect the total household income. Nevertheless, from the previous studies, the missing link is crop-livestock diversification patterns and its impact on household income that obtained from various income sources. From the total farm incomes, sale of crop yields, animals and their products and agro-forestry products accounted for 55.4, 26.4, and 18.2\%, respectively. Payment for retirement, remittance, masonry, carpentry, petty trading, and related activities were the major source of non-farm income. In Gudo Beret watershed, the main source of offfarm income was labour wage. The annual average total income was 4837 birr per household, which is equivalent to 225 dollars. However, there is a large variation among households on farmincome levels as they pursue different crop-livestock diversification patterns.

To determine the effect of crop-livestock diversification on household income, the major components or crop-livestock diversification patterns are considered as explanatory variables. The total annual income level of households then regressed against the 
major components using OLS regression procedures. The result is presented in Table 5.

Table 5: Effects of crop-livestock diversification patterns on household income

\begin{tabular}{lrrr}
\hline $\begin{array}{l}\text { Diversification } \\
\text { patterns }\end{array}$ & Coefficients & Std. Err. & t-value \\
\hline Sheep and goat & $59.86 * * *$ & 22.72 & 2.63 \\
Staple crops & 5.74 & 24.27 & 0.24 \\
Chicken & $38.31 * *$ & 15.95 & 2.40 \\
Vegetables & $45.84 *$ & 23.61 & 1.94 \\
Animal feed & 2.65 & 19.89 & 0.13 \\
Constant & $224.99 * * *$ & 15.66 & 14.36 \\
R-square & & & 0.12 \\
F-value & & & $3.43 * * *$ \\
\hline Note: $* * * * *, *$ significant at $1 \%, 5 \%$, and $10 \%$ &
\end{tabular}

The results in Table 5 revealed that sheep and goat, chicken, and vegetable-based diversification were positively correlated with household income and significant at $1 \%, 5 \%$ and $10 \%$, respectively. As diversification for sheep and goat, chicken, and vegetablebased farming increases by each of one standardized unit, household income increases by 59.86, 38.31, and 45.84 dollars, respectively. It implies that small body size animals (chicken, sheep, and goat) and vegetables such as onion, tomato, and potatoes grown with supplementary irrigation were the major sources of farm income for rural households. Intensive production of small ruminants in the private, communal and open access grazing lands bring high economic returns that served mainly for home consumption and cash incomes.

\section{DISCUSSION}

The focus of this study is to identify crop-livestock diversification pattern, determinants of diversification and its effect on household income. Sheep and goat, staple crops, vegetables, chicken, and animal feed (Oats)-based diversifications are identified patterns. Most of croplivestock activities are integrated within and among different patterns in the farming systems. Diversified farming has incentives not only to enhance household income but also lessons competition among crop-livestock activities. Patterns of production for sheep and goat, vegetables, and chicken are positively associated with household incomes.

The most significant and predominant diversification pattern is sheep and goat, which is associated with equine, cattle and cereal production. In this pattern, the highest factor loading is for sheep and goat production. The average holding size of sheep is seven per household whereas goat is very limited in size between zero and one animal per household. In our study, like many previous studies did, for instance, Iiyama et al. (2007a), sheep and goat are under one category. In the study area, the proportion of households that own sheep and goat is $82 \%$ and $18 \%$, respectively. It implies that sheep is the most potential livestock breed in this highland agro-climate. Edea et al. (2012) also pointed out that sheep is the most diversified breeds and the main source of livelihood in many parts of Ethiopia. It is also a source of meat, skin, manure and coarse wool or long hairy fleece (Mengesha and Tsega, 2012). In this study, it is found the most influential source of household annual income.

Chicken-based diversification pattern is the third component in the mixed crop-livestock systems. Chicken production is the leading activity after sheep rearing. The average holding size of chicken is 4.5 per household. Beekeeping, improved cattle, and oil crops are integrated with this pattern. In contrast, indigenous cattle, equine, chicken, pulse crops, vegetables, and oats are correlated negatively with the pattern. Chicken production is one of the identified opportunities for smallholder where small landholding size is prevalent. The study area has suitable agro-climate for chicken production.

Some activities (beekeeping and cereal crops) are integrated with vegetable-based diversification pattern whereas activities such as pulses, oil crops and the majority of livestock species are competed with this pattern. Depending on availability of land and agroclimate suitability, vegetables can be grown either as sole crop or intercropped with other vegetables or cereals through rain-fed or supplementary irrigation systems. Ethiopia is potentially profitable and comparative advantage in production of vegetables because its favourable climate, cheap labour, market proximity to Europe, and rivers for irrigation (Ashebre, 2015).

\section{CONCLUSIONS}

Mixed crop-livestock production is one of the major livelihood strategies in rural highlands of Ethiopia. Diversified farming is the major source of food, cash income, and agro-ecological services. Nevertheless, crop production has competed with the livestock sub-systems for land resources. Hence, households have prioritized major farming patterns in the crop-livestock systems to minimize competitions among farm activities and reduce pressures on land resources. Male-headed households are potential producers of sheep-based diversification pattern, while chicken-based diversification pattern or small-scale poultry production is appropriated for landless and rural women.

Households that have access to adequate farmlands are found to adopt crop production in general, and, grain and vegetable-based farming systems in particular. In the same way, access to irrigation lands enabled to adopt irrigation-based farming, whereas households led by educated farmers had adverse effects on crop-based farming systems because they shift their decision mainly from crop production to off-farm and non-farm activities. Overall, diversified farms are the source of income for the majority of households, which can improve the livelihoods of farm households. Among the identified farming typologies, sheep and vegetable-based farming were the major source of income followed by chickenbased farming systems. Women friendly agricultural technologies and agro-climate adaptive practices such as small-scale vegetable production, chicken rearing and sheep-based farming patterns should be encouraged to improve the livelihood of smallholder farmers in the study area. 


\section{Acknowledgements}

The authors would like to thank the sample respondents, enumerators and district experts for their valuable response during data collection process.

\section{REFERENCES}

ABATE, A. (2014). Assessing the Consequence of Land Use Change on Agricultural Productivity in Nadda Asendabo Watershed Gilgel Gibe Sub-Catchment of Ethiopia. Int. J. Environ. Sci, 3(2), p. 72-77.

ABDI, H., \& WILLIAMS, L. J. (2010). Principal Component Analysis. Wiley Interdisciplinary Reviews: Computation Stat, 2(4), p. 433-459. DOI: https://doi.org/10.1002/wics.101

ALEMAYEHU, S., DOROSH, P., \& SINAFIKEH, A. (2011). Crop Production in Ethiopia: Regional Patterns and Trends: International Food Policy Research Institute (IFPRI). ESSP II Working Paper No. 0016.

ANDERSON, J. R., \& FEDER, G. (2003). Rural extension services. Agriculture and Rural Development Department, Working paper 2976. World Bank, Washington, DC. http://econ.worldbank.org.

ASANTE, B. O., VILLANO, R. A., PATRICK, I. W., \& BATTESE, G. E. (2017). Determinants of Farm Diversification in Integrated Crop-Livestock Farming Systems in Ghana. Renewable Agri. Food Sys, 1-19. DOI: https://doi.org/10.1017/S1742170516000545

ASHEBRE, K.M. (2015). Opportunities and Potential in Ethiopia for Production of Fruits and Vegetables: A Graduate Senior Seminar Paper. African Journal of Basic \& Applied Sciences 7 (6), p. 328-336. DOI: 10.5829/idosi.ajbas.2015.7.6.1153

BERHE, A.A. (2011). Coping with Drought for Food Security in Tigray, Ethiopia. MSc Thesis. Wageningen, the Netherlands.

BOSERUP, E. (1965). The Conditions of Agricultural Growth: The Economics of Agrarian Change under Population Pressure. London, Allen and Unwin.

BOSERUP, E. (1981). Population and Technological Change: A Study of Long-term Change: Chicago, University of Chicago Press.

CADAVEZ, V., \& HENNINGSEN, A. (2012). The Use of Seemingly Unrelated Regression (SUR) to Predict the Carcass Composition of Lambs. Meat Science, 92, p. 54853. DOI: https://doi.org/10.1016/j.meatsci.2012.05.025

DANIEL, D. (2010). Sustainable Land Management Technologies and Approaches in Ethiopia, Addis Ababa, Ethiopia, MoARD.

DINKU, A.M. (2018). Determinants of livelihood diversification strategies in Borena pastoralist communities of Oromia regional state, Ethiopia. Agriculture and Food Security, 7:41. DOI: https://doi.org/10.1186/s40066-018-0192-2 .

EDEA, Z., HAILE, A., TIBBO, M., SHARMA, A. K., SOLKNER, J., \& WURZINGER, M. (2012). Sheep production systems and breeding practices of smallholders in western and south-western Ethiopia: Implications for designing community-based breeding strategies. Livestock Research for Rural Development, Vol. 24, (117). http://www.lrrd.org/lrrd24/7/edea24117.htm.
FAO, (2014). Analysis of Price Incentives for Wheat in Ethiopia. Technical Notes Series, MAFAP, by Wakeyo M B, Lanos B, Rome.

GREENE, W. H. (2002). Econometric Analysis. 5 ${ }^{\text {th }} \mathrm{ed}$. New Jersey. Prentice-hall Inc.

GUJARATI, D. N. (2003). Basic Econometrics. New York: McGraw Hill Book Co.

HAREGEWEYN, N., TSUNEKAWA, A., NYSSEN, J., POESEN, J., TSUBO, M., MESHESHA, D. T., SCHÜTT, B., ADGO. E., \& TEGEGNE, F. (2015). Soil Erosion and Conservation in Ethiopia: A Review. Prog. Phys. Geog, 39(6): 750-774.

DOI:

https://doi.org/10.1177/0309133315598725

HERRERO, M., THORNTON, P. K., NOTENBAERT, A., MSANGI, S., WOOD, S., \& KRUSKA, R. (2012). Drivers of Change in Crop-Livestock Systems and their Potential Impacts on Agro-Ecosystems Services and Human Wellbeing to 2030. A Study Commissioned by the CGIAR System wide Livestock Programme. Addis Ababa, Ethiopia: ILRI.

HOFFMAN, L. A., \& LIVEZEY, J. (1987). The U.S. OATS Industry, Commodity Economics Division, Economic Research Service, U.S. Department of Agriculture. Washington, DC. Agricultural Economic Report No. 573.

IFAD. INTERNATIONAL FUND FOR AGRICULTURAL DEVELOPMENT. (2010). Inte grated Crop-livestock Farming Systems. Livestock Thematic papers. Tools for Project Design. Pp. 8.

IFAD. INTERNATIONAL FUND FOR AGRICULTURAL DEVELOPMENT. (2013). Smallholders, Food Security and the Environment. pp. 54. IIYAMA, M., KAITIBIE, S., KARIUKI, P., \& MORIMOTO, Y. (2007). The Status of Crop-Livestock Systems and Evolution toward Integration. Ann. Arid Zone, $\quad 46 \quad(3 \quad-4), \quad$ p.1-23. DOI: https://hdl.handle.net/10568/2459.

IIYAMA, M., MAITIMA, J., \& KARIUKI, P. (2007). Crop-Livestock Diversification Patterns in Relation to Income and Manure Use: A Case Study from a Rift Valley Community, Kenya. Afr. J. Agr. Res, 2(3), p. 058-066.

ILO. INTERNATIONAL LABOR ORGANIZATION. (2014). Decent Work Country Program 2014-15, Ethiopia. KASSIE, G. W., KIM, S., \& FELLIZAR, F. P. (2017). Determinant Factors of Livelihood Diversification: Evidence from Ethiopia. Cogent Social Sci, 3: 1369490. DOI: $10.1080 / 23311886.2017 .1369490$

KEBEDE, T., HAJI, J., BELAINEH LEGESSE, B. \& MAMMO, G. (2016). Econometric Analysis of Rural Households' Resilience to Food Insecurity in West Shoa, Ethiopia. J. Food Secur, 4(3), p. 58-67. DOI: 10.12691/jfs-4-3-2.

Keho, Y. (2012). The Basics of Linear Principal Components Analysis. In Principal Component Analysis. DOI: $10.5772 / 38577$.

KURIA, A., LAMOND, G., PAGELLA, T., GEBREKIRSTOS, A., HADGU, K., \& SINCLAIR, F. (2014). Local knowledge of farmers on opportunities and constraints to sustainable intensification of croplivestock- trees mixed systems in LemoWoreda, Southern Nations Nationalities and People Region (SNNPR), Ethiopian highlands. A field study report. 
https://cgspace.cgiar.org/bitstream/handle/10568/41669/ Lemo_ARmay.pdf?sequence $=1$ \&isAllowed $=y$

LEBEDA, P., CHAMBERS, Z., DESTRÉE, A., DOLEŽAL, J., LUKÁŠ, I., MARČÍK, F. MARITZ, CH. \& MILEROVÁ-PRÁŠKOVÁ, D. (2010). Ethiopia's Food Insecurity: Europe's Role within The Broader Context of Food Flows, Climate Change and Land Grabs. Glopolis, Prague.

LESSCHEN, J. P., \& VERBURG, P. H. (2005). Statistical methods for analysing the spatial dimension of changes in land use and farming systems. LUCC Report Series 7 Land-Use and Land-Cover Change (LUCC) Project. IV International Human Dimensions Programme on Global Environmental Change (IHDP) V. International Geosphere-Biosphere Programme (IGBP)

LIEW, H. (2017). Health and well-being of middle age Indonesians: An application of seemingly unrelated regression (SUR) models. Health Policy and Technology, 6, p. 322-327. DOI: https://doi.org/10.1016/j.hlpt.2017.07.002

LIN, B. B. (2011). Resilience in Agriculture through Crop Diversification: Adaptive Management for Environmental Change. Bioscience, 61(3), p. 183-193. DOI: https://doi.org/10.1525/bio.2011.61.3.4

LINIGER, H., MEKDASCHI, S. R., HAUERT, C., \& GURTNER, M. (2011). Guidelines and Best Practices for Sub-Saharan Africa: Field Application, FAO.

MAGURRAN, A. E. (2004). Measuring Biological Diversity. Blackwell Science Ltd.

MANYONG, V. M., OKIKEB, I., \& WILLIAMS, T. O. (2006). Effective Dimensionality and Factors Affecting Crop-Livestock Integration in West African Savan NRC: A Combination of Principal Component Analysis and Tobit Approaches. Agricultural Economics, 35, p. 145155. DOI: $\quad$ https://doi.org/10.1111/j.15740862.2006.00148.x

MARTIN, G., MORAINE, M., RYSCHAWY, J., MAGNE, M-A., ASAI, M., SARTHOU, J. P., DURU, M., \& THEROND, O. (2016). Crop-livestock integration beyond the farm level: A review. Agronomy for Sustainable Development, Springer Verlag/EDP Sciences/INRA, 36 (3), pp. 53. DOI: 10.1007/s13593$\underline{016-0390-X}$

MATSANE, S. H., \& OYEKALE, A. S. (2014). Factors Affecting Marketing of Vegetables among Small-scale Farmers in Mahikeng Local Municipality, North West Province, South Africa. Mediterranean Journal of Social Sciences, 5(20), p. 390-397. DOI: DOI: $10.5901 / \mathrm{mjss} .2014 . v 5 \mathrm{n} 20 \mathrm{p} 390$

MCINTIRE, J., BOURZAT, D., \& PINGALI, P. (1992). Crop-Livestock Interaction in Sub-Saharan Africa. Washington DC. World Bank.

MEKURIA, W., MEKONNEN, K., THORNE, P., MELKAMU BEZABIH, M., TAMENE, L. \& ABERA, W. (2018). Competition for land resources: Driving forces and consequences in crop-livestock production systems of the Ethiopian highlands. Ecological process, 7(30), p. 115. https://doi.org/10.1186/s13717-018-0143-7

MEKURIA, W., NEGATU, W., \& MEKONNEN, K. (2017). Adoption of Improved Dairy Cows and Implications for Household Food Security: Evidence in Central Highland of Ethiopia. Global Journal of Science
Frontier Research: D Agriculture and Veterinary, 17(3), p. 29-37.

MENGESHA, M., \& TSEGA, W. (2012). Indigenous Sheep Production in Ethiopia: A Review. Iranian Journal of Applied Animal Science, 2(4), p. 311-318. http://ijas.iaurasht.ac.ir/article 514280.html

MESFIN, W., FUFA, B., \& HAJI, J. (2011). Pattern, trend and determinants of crop diversification: Empirical evidence from smallholders in Eastern Ethiopia. J. of Econ. and Sustainable Devt. 2(8), p. 78-89.

MORAINE, M., DURU, M., NICHOLAS, P., LETERME, P., \& THEROND, O. (2014). Farming System Design for Innovative Crop-livestock Integration in Europe. Animal, 8(8), p. 1204-1217. DOI: https://doi.org/10.1017/S1751731114001189

NIGUSSIE, Z., \& ALEMAYEHU, G. (2013). Levels of Household Food Insecurity in Rural Areas of Guraghe Zone, Southern Ethiopia. J. Agr. Res, 2 (1), p. 008-014.

NKONYA, E., GERBER, N., BAUMGARTNER, P., von BRAUN, J., De PINTO, A., GRAW, V., KATO, E., KLOOS, J., \& WALTER, T. (2011). The Economics of Desertification, Land Degradation, and Drought: Toward an Integrated Assessment. ZEF Discussion Paper on Development Policy No. 150, Centre for Development Research, Bonn. Pp. 184. DOI: http://dx.doi.org/10.2139/ssrn.1890668

OCHIENG, J., OWUOR, G., \& BEBE, B. O. (2012). Determinants of Adoption of Management Interventions in Indigenous Chicken Production in Kenya. AfJARE, 7(1), p. 39-50. DOI: 10.22004/ag.econ. 156977

OJO, M. A., OJO, A. O., ODINE, A. I., \& OGAJI, A. (2014). Determinants of Crop Diversification among Small-scale Food Crop Farmers in North Central Nigeria. PAT Dec, 10(2), p. 1-11.

REHIMA, M., BELAY, K., DAWIT, A., \& RASHID, S. (2013). Factors Affecting Farmers' Crop Diversification: Evidence from SNNPR, Ethiopia. Int. J. Agri. Sci, 3(6), p. 558-565.

RUDEL, T. K., KWON, O., PAUL, B. K., BOVAL, M., RAO, I. M., BURBANO, D., MCGRODDY, M.; LERNER, A.M., WHITE, D., CUCHILLO, M., LUNA, M., \& PETERS, M. (2016). Do Smallholder, Mixed CropLivestock Livelihoods Encourage Sustainable Agricultural Practices? A Meta-Analysis. Land, 5 (6): 6; DOI: $\underline{\text { https://doi.org/10.3390/land5010006 }}$

SHAHBAZ, P., BOZ, I., UL HAQ, SH. \& KHALID, U. B. (2017). Mixed Farming and Its Impact on Farm Income: A study in District Faisalabad, Punjab Pakistan. IJRDO- Journal of Agriculture and Research, 3(8), p. 1625.

SHIDEED, K. H., \& EL MOURID, M. (eds.) (2005). Adoption and Impact Assessment of Improved Technologies in Crop and Livestock Production Systems in the WANA Region. The Development of Integrated Crop/Livestock Production in Low Rainfall Areas of Mashreq and Maghreb Regions. ICARDA, Aleppo, Syria. Pp. 160.

SIBHATU, K. T., KRISHINA, V. V., \& QAIM, M. (2015). Production Diversity and Dietary Diversity in Smallholder Farm Households. Proceedings of the National Academy of Sciences (PNRC), 112(34), p. 
$10657-10662$.

www.pnas.org/cgi/doi/10.1073/pnas.1510982112

SISAY, Y., DEGSEW, M., \& MEKURIA, W. (2018). The

Status of Household Food Insecurity: The Case of West Belesa, North Gondar, Amhara Region, Ethiopia. International Journal of Scientific Research and Management (IJSRM), 6(6), p. 158-166. DOI: https://doi.org/10.18535/ijsrm/v6i6.ah02

TADESSE, S. A., \& TAFERE, S. M. (2017). Local people's knowledge on the adverse impacts and their attitudes towards growing Eucalyptus woodlot in Gudo Beret Kebele, Basona Worena district, Ethiopia. Ecol Process 6, 37 p. 3-13. DOI: https://doi.org/10.1186/s13717-017-0105-5
TODARO, M. P., \& SMITH, S. C. (2012). Population Growth and Economic Development: Causes, Consequences, and Controversies. Economic development. Eleventh edition. Boston: Pearson Addison Wesley.

UNDP. United Nations Development Program. (2018). Ethiopia: National Human Development Report 2018. Industrialization with a Human Face. Addis Ababa, Ethiopia. 